Tropical Journal of Pharmaceutical Research October 2010; 9 (5): 463-467

(C) Pharmacotherapy Group,

Faculty of Pharmacy, University of Benin,

Benin City, 300001 Nigeria.

All rights reserved.

Research Article

Available online at http://www.tjpr.org

\title{
Acute and Sub-chronic (28-day) Oral Toxicity Studies of Hydroalcohol Leaf Extract of Ageratum conyzoides L (Asteraceae)
}

\author{
Aboudoulatif Diallo', Kwashie Eklu-Gadegkeku', Amegnona \\ Agbonon ${ }^{1}$, Kodjo Aklikokou', Edmond E Creppy², Messanvi \\ Gbeassor $^{1}$ \\ ${ }^{1}$ Department of Animal Physiology, Faculty of Sciences, University of Lome, Togo, ${ }^{2}$ Department of Toxicology, \\ Laboratory of Toxicology and Applied Hygiene, University Victor Segalen Bordeaux 2. Bordeaux, France
}

\begin{abstract}
Purpose: Ageratum conyzoides is an annual herbaceous plant commonly used in African traditional medicine as a purgative, antipyretic, anti-ulcer and wound dressing agent. The objective of this study was to investigate the acute and sub-chronic toxicity of $A$. conyzoides leaves in Wistar rats.

Methods: In the acute test, the limit test dose of $5000 \mathrm{mg} / \mathrm{kg}$ was administered to Wistar rats and then observed individually $1 \mathrm{~h}$ post-dosing, and at least once daily for 14 days. Sub-chronic toxicity was evaluated after administering daily oral doses of 500 and $1000 \mathrm{mg} / \mathrm{kg}$ body wt., for 28 days to the rats, Biochemical and haematological assessments as well as body and relative organ weights of the rats were carried out

Results: The limit dose of $5000 \mathrm{mg} / \mathrm{kg}$ did not cause any mortality or signs of acute toxicity in the rats tested during the observation period. In the sub-chronic tests, the results did not show any treatmentrelated abnormalities in terms of haematological and biochemical parameters. However, urea was significantly $(p<0.05)$ lower in the group treated with $500 \mathrm{mg} / \mathrm{kg}$ of $A$. conyzoides extract. The weekly body and organ weight of the rats showed no significant differences between the control and the rats treated with the extract except for liver where there was a significant increase $(p<0.05)$ in rats that received $1000 \mathrm{mg} / \mathrm{kg}$, i.e., $3 \pm 0.2 \mathrm{~g}$ as against $2.5 \pm 0.1 \mathrm{~g}$ for the control.

Conclusion: Our results suggest that the hydroalcohol extract of $A$. conyzoides is relatively safe when administered orally in rats.
\end{abstract}

Keywords: Ageratum conyzoides, Acute and sub-chronic toxicity, Biochemical parameters, Haematological analysis, Wistar rats.

*Corresponding author: E-mail: aboudoulatif@yahoo.fr; Tel: +228-3203332. Fax: +228-2218595 


\section{INTRODUCTION}

Ageratum conyzoides is an erect, annual herbaceous plant. It is known to possess a broad spectrum of pharmacological and therapeutic properties [1]. In African traditional medicine, $A$. conyzoides has been used as a purgative, antipyretic, anti-ulcer and wound dressing agent [2]. In Togo, it is used to treat fever, measles and snake bites [3] while in Nigeria this plant is used for skin diseases, wound healing, diarrhoea, pain associated with navel in children [4], and in the treatment of HIV/AIDS [5].

Phytochemical investigations on $A$. conyzoides have identified a number of secondary metabolites such us flavonoids, coumarins and alkaloidal compounds [6-8]. Horie et al [7] reported the presence of hexametoxyflavone and 1-2 benzopirone while Moore et al [8] identified several alkaloids including 1.2-desifropirrolizidinic and licopsamine which are hepatotoxic [8]. Other compounds such as tannins have also been detected $[9,10]$. However, the toxicity, including hepatotoxicity, of this plant has not been extensively studied $[4,11]$. In view of the presence of hepatotoxic alkaloids in $A$. conyzoides and the lack of toxicity study on the leaf extract, the objective of this study was to investigate the acute and sub-chronic toxicity of $A$. conyzoides leaves in Wistar rats.

\section{EXPERIMENTAL}

\section{Collection and extraction of plant materials}

A. conyzoides was collected from Djagblé, Togo, in July 2007. It was identified by Prof Kouami Kokou from the Botany Department of University of Lome, Lome, Togo and a voucher specimen was kept in the herbarium of the Laboratory of Botany and Plant Ecology, Faculty of Science, University of Lome with reference no. 212 of Tchala.

The leaves of the plant were air-dried to a constant weight and ground to a coarse powder. The dried powder (250 g) was soaked in $2 \mathrm{~L}$ of ethanol-water (90:10) for 72 $\mathrm{h}$ with occasional agitation. The solution was filtered and evaporated using a rotary evaporator, giving a dry extract yield of 15.9 $\%$. Appropriate concentrations of the extract were made in $2 \%$ aqueous Tween 80 and used in the animal experiments.

\section{Animals}

Wistar rats of either sex (150 - $200 \mathrm{~g})$, provided by the Department of Animal Physiology, were used. They were housed in a standard environmental condition and fed with rodent standard diets and water ad libitum. Animal care and handling conformed to accepted guidelines [12,13]. Ethical approval was obtained from the institutional Ethical Committee for Teaching and Research (ref no. CNCB- CEER 2801/2010).

\section{Acute toxicity test}

The limit test dose of $5000 \mathrm{mg} / \mathrm{kg}$ was used as stipulated in Organization for Economic Cooperation Development (OECD) guidelines [12]. Three female rats, each sequentially dosed at intervals of $48 \mathrm{~h}$, were used for the test. The animals were observed individually for acute toxicity signs and behavioural changes $1 \mathrm{~h}$ post-dosing, and at least once daily for 14 days.

\section{Sub-chronic toxicity test}

Repeat-dose oral toxicity study was carried out according to OECD guideline 407 [13]. The animals were divided into three groups of 8 animals each (4 males and 4 females). Group 1 received $10 \mathrm{ml} / \mathrm{kg}$ body weight of distilled water and served as control. Groups 2 and 3 received extract doses of 500 and $1000 \mathrm{mg} / \mathrm{kg}$ body wt, respectively. The extract was administered daily for 28 days the same time daily and observed at least twice daily for morbidity and mortality. Body weights of the animals were evaluated weekly.

Trop J Pharm Res, October 2010; 9 (5):464 
On the $29^{\text {th }}$ day, after an overnight fast, the rats were anaesthetized with ether and blood sample for haematological and biochemical analysis were collected into tubes with and without EDTA, respectively. Haemoglobin, haematocrit, red blood cell count, white blood cell count, mean corpuscular haemoglobin concentration $(\mathrm{MCHC})$, mean corpuscular haemoglobin $(\mathrm{MCH})$, mean corpuscular volume (MCV) and platelet count were determined using an automatic counter (Sysmex K21, Tokyo, Japan). Biochemical analysis was performed on serum obtained after centrifugation of total blood (without anticoagulant) at $2500 \mathrm{rpm}$ for $15 \mathrm{~min}$. Standardized diagnostic kits $\left(\right.$ Labkit ${ }^{\circledR}$ ) were used for spectrophotometric determination of the following biochemical parameters: alanine aminotransferase $(A L T)$, aspartate aminotransferase (AST), creatinine, alkaline phosphatase, glucose, total proteins and urea.

Necroscopy of all animals was carried and the organ weights (heart, liver, kidney and spleen) were recorded.

\section{Statistical analysis}

The results are expressed as mean \pm standard error of the mean (SEM). Statistical analysis was performed by one-way analysis of variance (ANOVA) with Tukey test to evaluate significant differences between groups. Values of $p<0.05$ were considered significant. All statistical analyses were carried out using the Instat statistical package (Graph Pad Software, Inc., USA).

\section{RESULTS}

\section{Acute toxicity}

The limit dose of $5 \mathrm{~g} / \mathrm{kg}$ did not cause mortality or any sign of acute toxicity in the three rats dosed for a short period (48 h) and long period (14 days).

\section{Sub-chronic toxicity}

No behavioural changes and death were observed at the end of the treatment. Similarly, no significant differences in body weight were observed between control and treated groups during this period (see Table 1).

Table 1: Mean body weight of rats after 28 days treatment with hydroalcohol leaf extract of $A$. conyzoides

\begin{tabular}{|c|c|c|c|}
\hline \multirow{3}{*}{ Week } & \multicolumn{3}{|c|}{ Mean body weight (g, \pm SEM) } \\
\hline & \multirow[t]{2}{*}{ Control } & \multicolumn{2}{|c|}{ Extract } \\
\hline & & $500 \mathrm{mg} / \mathrm{kg}$ & $\begin{array}{c}1000 \\
\mathrm{mg} / \mathrm{kg}\end{array}$ \\
\hline 0 & $132 \pm 4.8$ & $135 \pm 5.2$ & $129 \pm 4.5$ \\
\hline 1 & $139 \pm 5.4$ & $139 \pm 4.1$ & $133 \pm 4.2$ \\
\hline $\begin{array}{l}2 \\
3\end{array}$ & $\begin{array}{l}142 \pm 5.1 \\
148 \pm 4.8\end{array}$ & $\begin{array}{l}144 \pm 3.9 \\
151 \pm 4.4\end{array}$ & $\begin{array}{l}137 \pm 4.7 \\
143 \pm 5.4\end{array}$ \\
\hline 4 & $152 \pm 5.5$ & $156 \pm 5.2$ & $147 \pm 6.4$ \\
\hline
\end{tabular}

Fig 2 shows that the weight of liver in the group treated with $1000 \mathrm{mg} / \mathrm{kg}$ significantly higher $(p<0.05)$ than that of the control group. For other organs and at both doses tested, there were no changes in organ weight

Table 2: Mean organ weight of rats after 28 days treatment with hydroalcohol leaf extract of $A$. conyzoides

\begin{tabular}{llll}
\hline \multirow{2}{*}{ Organ } & \multicolumn{2}{c}{ Mean weight (g, \pm SEM) } \\
\cline { 2 - 4 } & & Control & \multicolumn{2}{c}{ Extract dose } \\
\cline { 3 - 4 } & & $500 \mathrm{mg} / \mathbf{k g}$ & $\mathbf{1 0 0 0 ~} \mathbf{~ m g} / \mathbf{k g}$ \\
\hline Heart & $0.34 \pm 0.02(8)$ & $0.33 \pm 0.01(8)$ & $0.34 \pm 0.01(7)$ \\
Liver & $2.50 \pm 0.12(8)$ & $2.70 \pm 0.11(8)$ & $3.00 \pm 0.15(7)^{*}$ \\
Spleen & $0.17 \pm 0.02(8)$ & $0.18 \pm 0.018(8)$ & $0.23 \pm 0.03(7)$ \\
Kidney & $0.55 \pm 0.08(8)$ & $0.54 \pm 0.020(8)$ & $0.60 \pm 0.03(7)$ \\
Testis & $1.30 \pm 0.08(4)$ & $1.00 \pm 0.26(4)$ & $1.00 \pm 0.23(4)$ \\
\hline
\end{tabular}

No. of rats/group indicated in parenthesis; * $p<0.05$, control group vs extract 
Tables 3 and 4 show the haematological and biochemical parameters for the rats after subchronic toxicity dosing

Table 3: Haematological parameters for rats after 28 days treatment with hydroalcoholic extract of $A$. conyzoides leaves.

\begin{tabular}{|c|c|c|c|}
\hline \multirow{2}{*}{ Parameter } & \multirow{2}{*}{ Control } & \multicolumn{2}{|c|}{ Extract dose } \\
\hline & & $\begin{array}{l}500 \\
\mathrm{mg} / \mathrm{kg}\end{array}$ & $\begin{array}{l}1000 \\
\mathrm{mg} / \mathrm{kg}\end{array}$ \\
\hline WBC $\left(10^{3} / \mu \mathrm{l}\right)$ & $9.7 \pm 0.9(8)$ & $9.9 \pm 0.9(7)$ & $8.7 \pm 1.3(7)$ \\
\hline $\operatorname{RBC}\left(10^{6} / \mu \mathrm{l}\right)$ & $7.4 \pm 0.1(8)$ & $6.9 \pm 0.4(7)$ & $7.0 \pm 0.2(7)$ \\
\hline $\begin{array}{l}\text { Haemoglobin } \\
(\mathrm{g} / \mathrm{dL})\end{array}$ & $14.0 \pm 0.4(8)$ & $14.0 \pm 0.4(7)$ & $13.0 \pm 0.4(7)$ \\
\hline $\begin{array}{l}\text { Haematocrit } \\
(\%)\end{array}$ & $42.0 \pm 0.9(8)$ & $40.0 \pm 2.2(7)$ & $41.0 \pm 1.4(7)$ \\
\hline MCV (fl) & $57.0 \pm 0.6(8)$ & $57.0 \pm 0.6(7)$ & $56.0 \pm 0.9(7)$ \\
\hline $\mathrm{MCH}(\mathrm{pg})$ & $18.0 \pm 0.4(8)$ & $20.0 \pm 1.5(7)$ & $19.0 \pm 0.4(7)$ \\
\hline $\mathrm{MCHC}(\%)$ & $32.0 \pm 0.6(8)$ & $35.0 \pm 2.4(7)$ & $33.0 \pm 0.8(7)$ \\
\hline $\begin{array}{l}\text { Platelet } \\
\left(10^{3} / \mu \mathrm{L}\right)\end{array}$ & $926 \pm 45(8)$ & $801 \pm 64(7)$ & $966 \pm 43(7)$ \\
\hline
\end{tabular}

Table 4: Biochemical parameters for rats after 28 days treatment with hydroalcohol extract of $A$. conyzoides leaves.

\begin{tabular}{|c|c|c|c|}
\hline \multirow{2}{*}{ Parameter } & \multirow[b]{2}{*}{ Control } & \multicolumn{2}{|c|}{ Extract dose } \\
\hline & & $\begin{array}{l}500 \\
\mathrm{mg} / \mathrm{kg}\end{array}$ & $\begin{array}{l}1000 \\
\mathrm{mg} / \mathrm{kg}\end{array}$ \\
\hline$\overline{\text { ASAT }(\mathrm{U} / \mathrm{L})}$ & $241 \pm 25(8)$ & $206 \pm 25(8)$ & $229 \pm 16(7)$ \\
\hline ALAT (U/L) & $69 \pm 11(8)$ & $66 \pm 5(8)$ & $60 \pm 7(7)$ \\
\hline $\begin{array}{l}\text { Total proteins } \\
(\mathrm{g} / \mathrm{dL})\end{array}$ & $6.0 \pm 2.2(8)$ & $6.2 \pm 1.8(8)$ & $6.5 \pm 1.4(7)$ \\
\hline $\begin{array}{l}\text { Creatinine } \\
(\mathrm{mg} / \mathrm{dL})\end{array}$ & $8.5 \pm 0.7(8)$ & $7.9 \pm 0.4(8)$ & $7.4 \pm 0.9(7)$ \\
\hline Urea (mg/dL) & $45 \pm 4(8)$ & $29 \pm 2(8)^{*}$ & $35 \pm 4(7)$ \\
\hline $\begin{array}{l}\text { Alkaline } \\
\text { phosphatase } \\
(\mathrm{U} / \mathrm{L})\end{array}$ & $273 \pm 52(8)$ & $215 \pm 45(8)$ & $225 \pm 56(7)$ \\
\hline
\end{tabular}

Only urea showed any significant change $(p$ $<0.05)$ being lower in the group treated with $500 \mathrm{mg} / \mathrm{kg}$ of the extract than in the control.
Other biochemical and haematological parameters were similar for the two groups.

\section{DISCUSSION}

The results of the acute toxicity study indicate that the $\mathrm{LD}_{50}$ of the extract of $A$. conyzoides extract is more than $5000 \mathrm{mg} / \mathrm{kg}$. The limit test is primarily used in situations where the investigator has information indicating that the test material is likely to be non-toxic or of low toxicity [12]. This finding, therefore, suggests that the extract at the limit dose tested is essentially non-toxic and safe in oral formulation. This result is in line with previous data from Moura et al [11] who reported that A. conyzoides $\mathrm{LD}_{50}$ in mice is more than $10,000 \mathrm{mg} / \mathrm{kg}$.

After 28 days of treatment, there were no treatment-related changes in haematological parameters between control and treated groups, indicating that the extract was not toxic to circulating red cells, nor interfered with their production and that of platelets. The haematopoietic system is one of the most sensitive targets of toxic compounds and is an important index of physiological and pathological status in man and animals [14]. In addition, most of the biochemical parameters were not also altered by the extract. The lack of significant alterations in the levels of ALT, AST, alkaline phosphatase, glucose and creatinine, which are good indicators of liver and kidney functions, suggests that sub-chronic administration of extract neither altered hepatocytes and kidneys of rats nor the normal metabolism of the animals. The extract produced significant decrease in urea levels at the lower dose $(500 \mathrm{mg} / \mathrm{kg})$; the reason is not exactly known but one possibility could be that the different active principles present in the extract are acting differently at the doses tested and moreover, some drugs are known to decrease blood urea levels [15].

The change in the relative weight of the liver and the presence of several alkaloids, including 1.2-desifropirrolizidinic and licopsa- 
mine, which can have hepatotoxic activity [13] indicate that the extract might have toxic potential on liver with increasing dose. However, it could be argued that these changes may not be toxicologically significant, as they were not corroborated by the biochemical findings (ALT, AST, alkaline phosphatase and glucose). Further histological study and more specific assays of toxicity could furnish more information regarding the hepatotoxicity of the extract.

\section{CONCLUSION}

Our results have demonstrated that the hydroalcohol leaf extract of $A$. conyzoides is relatively safe when administered orally in rats.

\section{REFERENCES}

1. Abena AA, Ouamba JM, Keita A. Anti-inflammatory, analgesic and antipyretic activities of essential oil of Ageratum conyzoides. Phytother Res 1996; 10: S164-S165.

2. Githen, TS. Fundamentals of Experimental Pharmacology. Scientific Book Agency.Calcutta; 1948. 153 p.

3. Adjanohoun EJ, Adjakidjé V, Ahyi MRA, Ake-Assi L, Akoegninou A., D’Almeida J., Apovo F., Boukef K., Chadare M., Cusset G. et al. Contribution aux études ethnobotaniques et floristiques en République populaire du Bénin. Agence de coopération culturelle et technique $1^{\text {st }}$ éd. Paris ; 1989. 698-699.

4. Okunade AL. Review: Ageratum conyzoides $L$. (Asteraceae). Fitoterapia 2002; 2: 1-16

5. Igoli JO, Ogaji OG, Tor-Anyiin TA, Igoli NP. Traditional medicine practice amongst the Igede people of Nigeria. Part II. Afr. J. Trad. Comp. Alt. Med. 2005; 2: 134-152
6. Vyas AS, Mulchandani NB. Polyoxygenated flavones from Ageratum conyzoides. Phytochemistry 1986; 25: 2625-2627

7. Horie $T$, Tominaga $H$, Kawamura Y. Revised structure of natural flavone from Ageratum conyzoides. Phytochemistry 1993 ; 32: 10761077

8. Moore DJ, Batts KP, Zalkow LL, Fortune GTJr, Powis G. Model systems for detecting the hepatic toxicity of pyrrolizidine alkaloides and pyrrolizidine alkaloid N-oxides. Toxicol. Appl. Pharmacol. 1989; 101: 271-284

9. Quijano L, Calderson JS, Gomez GF, Soria IE, Rios T. Highly oxygenated flavonoides from Ageratum conyzoides. Phytochemistry 1980; 19: 2439-2442.

10. Xuan TD, Shinkichi T, Hong NH, Khanh TD, Min CT. Assessment of phytotoxin action of Ageratum conyzoides $L$. on weeds. Crop Protection 2004; 23: 915-922.

11. Moura ACA, Silva ELF, Fraga MCA, Wanderley AG, Afiatpour $P$, Maia MBS. Anti-inflammatory and chronic toxicity study of leaves of Ageratum conyzoides $L$. in rats, Phytomedicine 2005; 12 : 138-142.

12. $O E C D$. Guidelines for the Testing of Chemicals / Section 4: Health Effects Test No. 423: Acute Oral toxicity - Acute Toxic Class Method. Organization for Economic Cooperation and Development, Paris, France; 2002.

13. OECD. Repeated dose oral toxicity test method. In: OECD Guidelines for testing of chemicals, $N^{\circ}$ 407. Organization for Economic Cooperation and Development, Paris, France; 2008.

14. Adeneye AA, Ajagbonna OP, Adeleke TI, Bello SO. Preliminary toxicity and phytochemical studies of the stem bark aqueous extract of Musanga cecropioides in rats. $J$ Ethnopharmacol 2006; 105: 374-379.

15. Kökdil G, Tamar L, Ercan B, Celik M, Atik U. Effects of Nigella orientalis and $N$. segetalis fixed oils on blood biochemistry in rats. Phytother Res 2006; 20: 71-75. 